\title{
DEMOCRATIC TELEVISION IN THE NETHERLANDS
}

\section{TWO CURIOUS CASES OF ALTERNATIVE MEDIA AS COUNTER-TECHNOLOGIES}

Tom Slootweg

Research Centre for Historical Studies University of Groningen, Faculty of Arts

Oude Kijk in 't Jatstraat 26

9712 EK, Groningen

The Netherlands

t.slootweg@rug.nl

Susan Aasman

Research Centre for Historical Studies University of Groningen, Faculty of Arts

Oude Kijk in 't Jatstraat 26 9712 EK, Groningen

The Netherlands s.i.aasman@rug.nl

\begin{abstract}
For this article, the authors retrieved two curious cases of non-conformist TV from the archives of the Netherlands Institute of Sound and Vision. Being made in the late 1970s and early 1980s, the two cases represent an alternative history of broadcast television in the Netherlands. Whereas Neon (1979-1980) aimed to establish a punk-inspired DIY video culture, Ed van der Elsken $(1980,1981)$ strived for an expressive amateur film culture. The authors propose to regard these cases as two different experiments on participation in and through media. By conceptualising amateur film and video as counter-technologies, the discursive expectations around their democratic potential can be explored further.
\end{abstract}

Keywords: counter-technologies, alternative media history, media participation, media archaeology, democratisation, broadcast television, amateur film and video, punk project, personal cinema

\section{Introduction}

From the archives of the Netherland Institute for Sound and Vision we retrieved two cases of remarkable television: the DIY punk-inspired video television series Neon (1979-1980) and two Super-8 home movie-like documentaries by filmmaker Ed van der Elsken (1980 and 1981). These offered an opportunity for the small public broadcaster VPRO, Neon's creators, and Ed van der Elsken to experiment with non-conformist television, even though they challenged the status quo of traditional broadcast TV. 
Both experiments attributed significance to alternative media technologies, such as portable video and small-gauge sound film. In their own fashion, they opposed the representational aesthetic as well as the top-down production and dissemination of content on public television in the Netherlands.

Our aim is to discover what these two cases, together with the discourses that surrounded them, can tell us about specific articulations of media participation and democracy in the late 1970s and early 1980s. We are especially interested in how these practices and discourses were related to alternative media technologies on the one hand, and broadcast TV on the other.

Serving as two examples of media revolutions that never happened, they can help us exemplify the recurring discursive struggle for alternative media to challenge established mass media infrastructures. In particular: how did these two cases from the late 1970 s and early 1980 s hope to bring about a democratic media revolution in the Netherlands?

In our research of these archival discoveries we followed a media archaeological approach. We believe that this approach can help counter the prevailing 'digital amnesia' towards ideas of participation and access as something that is only connected to Web 2.0 technologies. ${ }^{1}$ Starting from the technologies used in these two cases and contextualizing them in the discourses surrounding them, we wanted to unravel topoi like democratisation and participation as recurring motifs in media history. Connecting these two cases comes close to what media historian Erkki Huhtamo suggested, namely following traces of "lost media-cultural phenomena and agendas and to illuminate ideological mechanisms behind them."

We suggest that rather than looking at our two curious cases as dead ends in a more traditional broadcasting history approach, they can also be seen as interrelated early instances of media participation.

\section{Our Goals}

We aim to achieve two goals through our media archaeological approach. The first one is to offer a different view on television history. The history of broadcast television in Europe has often been told in terms of the rise and institutionalisation of national public broadcasters. ${ }^{3}$ Less attention has been devoted to the history of television as a site for experimentation in access and media participation. In short, we aim to enrich the history of broadcast TV by creating a counter-history.

In this article we try to reconstruct a particular moment in television history that can help us understand how alternatives were tried and tested, even though the results may not have been very visible or had lasting value.

This is certainly true for our two cases, which have not been very present in recent media historical studies. Despite their relative obscurity, they certainly are worth analysing. Television historian John Ellis addressed the question of enduring value of individual programmes that never made it to popular 'the best of' rankings. According to Ellis, much of the programming of broadcast TV is only 'temporarily meaningful' by its nature. ${ }^{4}$ That is, we will only understand such programmes if we read them in relation to the original contexts.

1 According to Jussi Parikka, media archaeology 'stepped in to challenge the strategic amnesia of digital culture.' See: Jussi Parikka, What is Media Archaeology?, Polity, 2012, p. 13.

2 Erkki Huhtamo, 'Dismantling the Fairy Engine: Media Archaeology as Topos Study,' in Jussi Parrika and Erkki Huhtamo, eds, Media Archaeology: Methods, Applications and Implications, University of California Press, 2011, p. 27-47, cf. p. 28.

3 See for instance: Andreas Fickers who recently concluded that the emergence of television in Western Europe could be characterised as a conservative media revolution. Andreas Fickers, 'The Emergence of Television as a Conservative Media Revolution: Historicising a Process of Remediation in the Post-War Western European Mass Media Ensemble,' in Journal of Modern European History, $10,1,2012$, p. 49-75.

4 John Ellis, 'Is it Possible to Construct a Canon of Television Programmes? Immanent Reading versus Textual Historicism,' in Helen Wheatley, ed, Re-Viewing Television History: Critical Issues in Television Historiography, Palgrave Macmillan, 2007, p. 15-26, cf. p. 25. 
We should therefore avoid singular approaches, as television historian Helen Wheatley instructs us. ${ }^{5}$ Wheatley suggests looking at production, text and reception as something that should be analysed and discussed in combination, rather than in isolation. With this approach she followed Lynn Spigel who in 1992 proposed the idea of 'conjunctural histories,' by which she meant that "rather than subscribing to a single historical truth," it is much more rewarding to "discover how television might have intersected with other social discourses and practices in the post-war era."

This 'conjunctural' approach opens up many possible cultural histories and it bears a strong resemblance with a media archaeological perspective, which also accomodates multiplicity and heterogeneity. But there is a difference as well. According to media scholar Jussi Parikka, media archaeology favours counter-histories as a way of understanding "how we came to the media cultural situation of our current digital world."

Our second goal is to propose a historiography of the avant-garde that sidesteps the often strictly divided histories of underground film and experimental video, which have often been understood as two separate movements. Broadly speaking, by the end of the 1970s and early 1980s there were two kinds of accessible alternative technologies available: small-gauge film and video. Both formats were surrounded by discourses of participation and democratisation, but at the same time, each in its own way, expressed a medium specific promise that those media technologies could become tools for and against television. In that sense, these media technologies each had their own trajectories.

The notion of small-gauge film as a possible alternative media technology had a long history that started in the late 1920 s. $^{8}$ At first, its potential was mostly understood in terms of alternative modes of production and dissemination alongside mass media institutions. ${ }^{9}$ Such a position could easily remain a marginal one, as was the case with underground cinema. It is only since the 1970 s when the idea started to take root that not only film formats like 16-mm, but also smaller gauges such as Super-8 could become part of making television.

Video had a much shorter history - with the first consumer video recorders and cameras being introduced from the late 1960s onwards - yet at the same time held a better position as an electronic medium within a mass media landscape dominated by television. Either as a means to record television content or to make one's own electronic footage, consumer video equipment was already intimately related to television technologies. From the onset of its emergence on the consumer market, artists embraced video technologies and rapidly attributed consumer video equipment with significance on the basis of either its profound radical artistic merits or political and participatory potential as an alternative medium. ${ }^{10}$

Despite these different trajectories, we propose to understand these technologies in conjunction rather than in opposition. Furthermore, we understand them to be part of a specific progressive worldview about media and democratisation in the 1970s and early 1980s.

5 Helen Wheatley, 'Introduction,' in idem, ed, Re-Viewing Television Histories: Critical Issues in Television Historiography, Palgrave Macmillan, 2007, p. 8.

6 Lynn Spigel and Denise Mann, eds, Private Screenings: Television and the Female Consumer, University of Minnesota Press, 1992, p. viii.

7 Parikka, What is Media Archaeology?, p. 6.

8 See for a historical account of the alternative use of film by the pre war British labour movement: Bert Hogenkamp, Deadly Parallels: Film and the Left in Britain, Lawrence and Wishart, 1986; for an account of postwar efforts of the Left to mobilise film (and television) as an alternative medium, see: Bert Hogenkamp, Film, Television and the Left, 1950-1970, Lawrence and Wishart, 2000. For an analysis of avant-garde film as alternative cinema and the avant-garde as alternative mode of filmmaking in the Netherlands, see: Céline Linssen, Hans Schoots and Tom Gunning, Het gaat om de film: Een nieuwe geschiedenis van de Nederlandsche Filmliga, 1927-1833, Uitgeverij Bas Lubberhuizen \& Filmmuseum, 1999.

9 Patricia Zimmermann wrote extensively about the discourses surrounding amateur film as both a domestic practice and as an avant-garde medium. See: Patricia Zimmermann, Reel Families: A Social History of Amateur Film, Indiana University Press, 1995. See also: Duncan Reekie, Subversion: The Definitive History of Underground Cinema, Wallflower Press, 2007.

10 Art historian and video artist Chris Meigh-Andrews analysed how artists appropriated video as a new technology to find alternative means to create and curate their work. See: Chris Meigh-Andrews, A History of Video Art: Second Edition, Bloomsbury, 2014 (2006), p. 13. For a two-part history of international video art published by the authoritative Zentrum für Kunst und Medientechnologie Karlsruhe (ZKM), see: Rudolf Frieling and Wulf Herzogenrath, eds, Record > Again: 40yearsvideart.de Part 1, Hantje Catz, 2009; and Christoph Blase and Peter Weibel, eds, Record > Again: 40yearsvideoart.de Part 2, Hantje Cantz, 2010. For two important early edited volumes with seminal scholarly and artistic reflections on video, art, and its social and political potential, see: Doug Hall and Sally Jo Fifer, eds, Illuminating Video. An Essential Guide to Video Art, Aperture Foundation, 1990; and Michael Renov and Erika Suderburg, eds, Resolutions: Contemporary Video Practices, University of Minnesota Press, 1996. See also: Chris Hill, ed, Rewind A Guide to Surveying the First Decade: Video Art and Alternative Media in the U.S., 1968-1980, Video Data Bank, 1995; Abina Manning and Brigid Reagan published a revised edition in 2008. 


\section{Alternative Media}

Inspired by the theoretical investigation of 'alternative media' by Bailey et al., we argue that our case studies exemplify two distinct experiments regarding participation in and through media. ${ }^{11}$ To summarise the distinction succinctly, participation in media refers to the infrastructure that enables non-professionals to "put into practice the right to communicate." 12 In other words, this form of media participation relates to possibilities of and access for non-professionals to be able to participate in the production and dissemination of content within institutionalised media, such as radio or television.

Participation through media, on the other hand, relates to the means with which "self-representation in public spaces" can come about. ${ }^{13}$ We understand this category of media participation especially in relation to the availability of and access to media technologies in order to express and represent oneself outside of the realm of institutionalised media.

In order to make this twofold understanding of media participation more productive in relation to our case studies, we propose to make a strict distinction between television, regarded as the dominant mass medium, and alternative media, understood as technological tools to be used progressively for and against television. Therefore we conceptualize the latter as counter-technologies.

This conceptualization will help us understand how these media were ascribed with a specific symbolic meaning as counter-technologies: namely, as tools to resist television aesthetically or politically, not only for the professional but also for the amateur. Thus, exploring their symbolic meaning will offer us an historical insight into the way in which the amateur and media technologies were attributed with a form of participatory agency, either in or through media.

\section{Reading Our Two Cases}

In what follows, the reader will find that our two cases can be read separately, without a strictly imposed order. Of course, there is a chronology when it comes to their broadcast dates, but we wonder if their chronological succession is meaningful enough to foreground in our article. Isolating them first and analysing them separately before we integrate these cases will help us to make our argument about the role of counter-technologies in an alternative television history.

To understand a little more of the Dutch television landscape, it is important to devote some additional words to its history in the 1960s and 1970s. Broadcaster VPRO, originally an acronym for the Liberal Protestant Broadcasting Association, had a strong tradition of experimentation and non-conformism, which it started to develop in those decades. ${ }^{14}$ The plurality of broadcasters in the Dutch public broadcasting system, where the VPRO was one among several others, was rather unique; it initially mirrored the politically, socially and culturally segmented, or 'pillarised,' structure of Dutch society as it existed throughout most of the twentieth century. ${ }^{15}$

Supported by the government on the basis of the number of membership contributions, the VPRO traditionally catered to the liberal protestant denomination in the Netherlands: via radio and television broadcasts, and with its radio and television guide, the VPRO Gids. However, running parallel to the societal transformation of the Western world in the

11 Baily et al. have argued that this twofold distinction has been a recurring trend in the conceptualisation of media participation. See: Olga Bailey, Bart Cammaerts and Nico Carpentier, Understanding Alternative Media, Open University Press, 2007, p. 11.

12 Idem.

13 Idem.

14 For an account of VPRO's internal struggle to renegotiate its identity and the first steps towards allowing more non-conformist experiments in its programming, see: Mirjam Prenger and René Witte, De sleutel van de VPRO: Een omroep en zijn ledenraad 1969-1994, Cramwinckel, 1994, p. 77. See also: Hans Blom, Burgerlijk en beheerst: Over Nederland in de twintigste eeuw, Uitgeverij Balans, 1996, p. 71-72.

15 For an English account of the development of the segmented structure in Dutch society - the 'verzuiling' ('pillarisation') of socialist, protestant, catholic and liberal communities in the Netherlands - see: Cees van der Eijck, 'The Netherlands: Media and Politics between Segmented Pluralism and Market Forces,' in Richard Gunther and Anthony Mughan, eds, Democracy and the Media: A Comparative Perspective, University of Cambridge

Press, 2000, p. 303-342. See also: Huub Wijfjes, 'Omroep in Nederland: Vijfenzeventig jaar medium en maatschappij, Waanders, 1994. 
Tom Slootweg and Susan Aasman, Democratic Television in the Netherlands

wake of the protest movements in the 1960s, the traditional segmentation of Dutch society slowly started to disintegrate. This also affected broadcasters such as the VPRO, who "reoriented itself in a secular, nonconformist, and libertarian direction." ${ }^{16}$ One of the results of this reorientation was that the VPRO allowed its programme makers to experiment with an innovative and often avant-garde attitude to explore non-conventional television. ${ }^{17}$

As television historian Sonja de Leeuw argued, other public broadcasters had to reorient themselves as well, ${ }^{18}$ especially the socialist broadcaster VARA (1925-), who followed a similar path. Like the VPRO, the broadcaster had to renegotiate its role within a changing broadcasting system and society. The VARA offered a chance to a new generation of programme makers. ${ }^{19}$ But when some of the programmes made by this new generation caused controversy, it resulted in a more hesitant attitude towards experimentation and non-conformism among the socialist broadcaster's leadership. ${ }^{20}$ Contrary to what happened at the VARA, the VPRO chose to publicly defend its independent programme makers, despite the occasional friction behind the scenes.
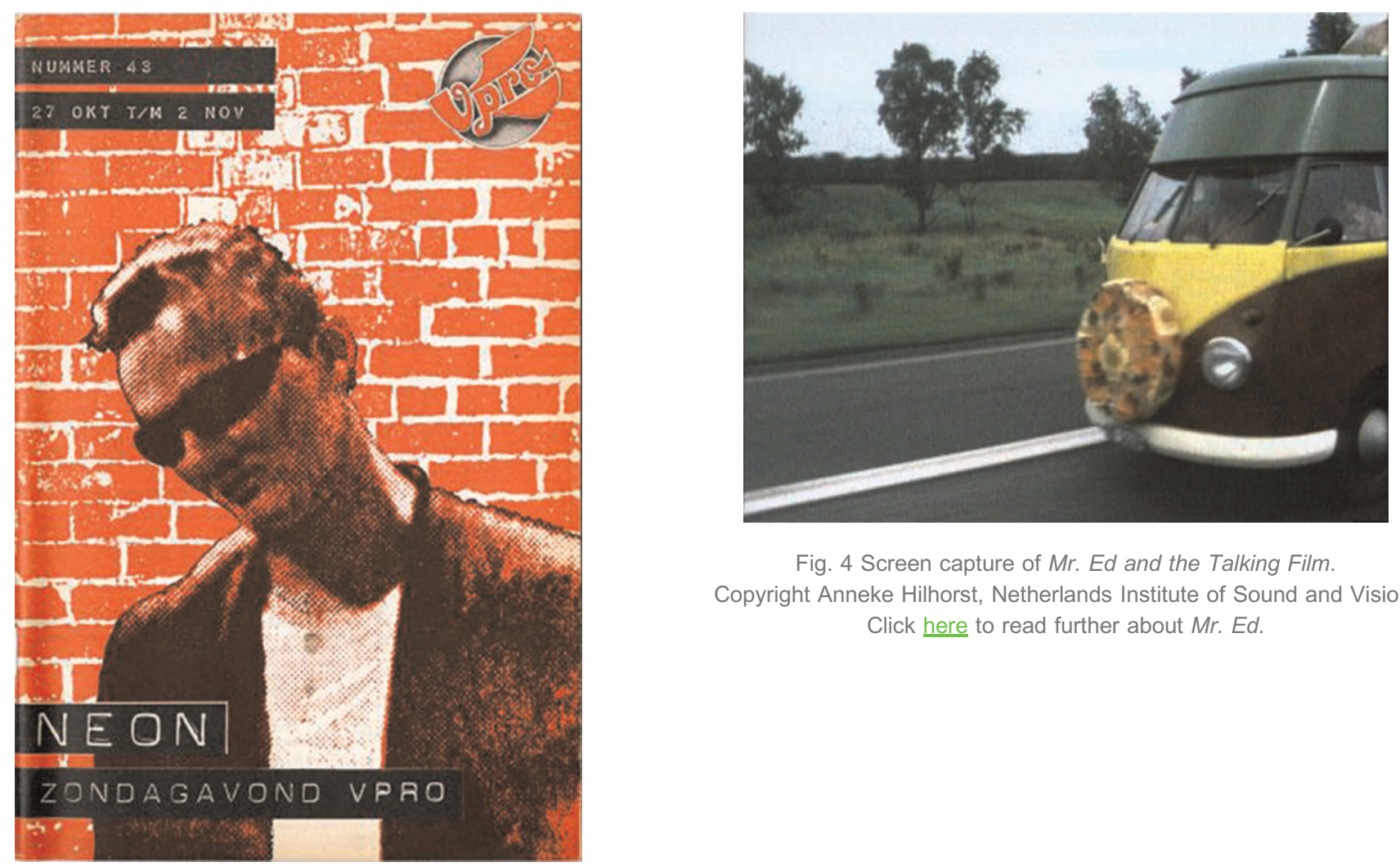

Fig. 4 Screen capture of Mr. Ed and the Talking Film. Copyright Anneke Hilhorst, Netherlands Institute of Sound and Vision. Click here to read further about $M r$. Ed.

Fig. 1 Front cover of De VPRO Gids no 43, 1979. Copyright VPRO.

Click here to read further about Case Neon.

17 Sonja de Leeuw, 'Televisie verbindt en verdeelt, 1960-1985,' in Bert Hogenkamp, Sonja de Leeuw and Huub Wijfjes, eds, Een eeuw van beeld en geluid: Cultuurgeschiedenis van radio en televisie in Nederland, Nederlands Instituut van Beeld en Geluid, 2012, p. 148-187: A seminal example is VPRO's Hoepla (1967), in which its Fluxus-inspired stylistic innovations worked in tandem with its controversial content. Idem, p. 151.

18 Idem, p. 153.

19 A generation that belonged to and was inspired by the countercultural movements of the 1960s. See: Huub Wijfjes, VARA: Biografie van een omroep, Boom, 2009, p. 241.

20 For an overview of VARA's experimental and non-conformist television and its internal and public reception, see: Wijfjes, VARA, p. 241-256. 
Tom Slootweg and Susan Aasman, Democratic Television in the Netherlands

\section{Case Neon}

\subsection{Neon and the Punk Project}

VPRO's Neon arrived on Dutch television in the early evening of Sunday October 7, 1979, and ended eight episodes later on April 13, 1980. In De VPRO Gids, some of the programme's independent creators (among others, Bob V., Derk Tilt, Ireen van D.) were introduced semi-anonymously or under an alias, thereby suggesting they are part of an anonymous group of provocative youngsters living on the fringes of society. For a while they tried to keep their identities secret and refused to give any elaborate interviews. ${ }^{21}$

The first episode ('Neon l') consists of several distinctive components, among which concert registrations, seemingly amateur-made film and videos, poetry and electronic soundscapes were the most prominent. The concerts were recorded with a portable video camera on stage according to the ethos of punk bands. Punk music scholar John Encarnacao argued that the punk ethos was based on several notions, of which low-fidelity, authenticity and a do-ityourself (DIY) attitude were the core constituents. In terms of punk's cultural production, this attitude crystallized in "practices that place[d] a premium on independence, domestic activity, rawness and spontaneity, and participation and inclusion." 22

This multifaceted ethos can also be traced in the other elements of Neon. Several unpolished low-quality video items about hooliganism and youthful acts of vandalism conveyed an aesthetic of rawness and spontaneity that was uncommon on Dutch broadcast TV. Moreover, in what was called a 'Neon code,' the programme showcased a disruptive audiovisual collage of around one and a half minutes. It can be argued that these disruptions resulted from

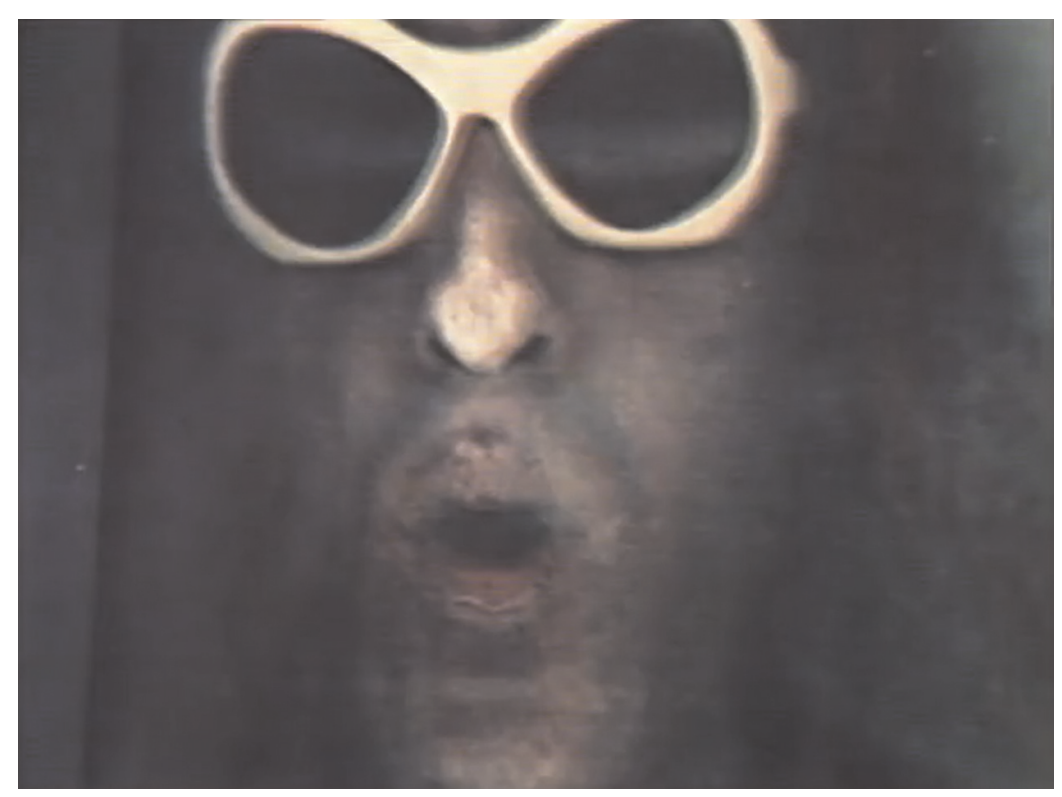

Fig. 2 Screen capture from a fragment of a NEON code. Go to the online version of this article to see the full video, with additional footage of school vandalism. Copyright Netherlands Institute of Sound and Vision.

21 Rien Vroegindewij, 'Multinational Rotterdam,' De VPRO Gids 43, September \& October 1979, p. 3-4. We have decided to bring the names of the historical actors associated to Neon and the VPRO to the background. We have done so, in order to keep the article concise and within the word limits. For a more elaborate account of the historical actors involved, see the forthcoming PhD dissertation by Tom Slootweg.

22 Although he does not argue that these characteristics emerged during the punk movement, he does underline that punk 'had much to do with assembling, codifying, and amplifying them.' See: John Encarnacao, Punk Aesthetics and New Folk: Way Down the Old Plank Road, Ashgate, 2013, p. 8-9. For a sociological reflection on punk as a subculture, see: Andy Bennett, Cultures of Popular Music, Open University Press, 2003, p. 58-73. 
Tom Slootweg and Susan Aasman, Democratic Television in the Netherlands

what media theorist and sociologist Dick Hebdige theorised as an 'anarchic' mode of 'bricolage:' the dominant form of cultural production in punk subcultures. ${ }^{23} \mathrm{~A}$ particularly striking example can be found in the second half of the first episode.

In this clip we see how an intricate audiovisual juxtaposition was created between a still photograph of a poster that announced an upcoming $8 \mathrm{~mm}$ film festival in the Hague, video footage of flickering neon tubes and vandalized school lavatory tiles, electronically modulated women's voices that repetitively articulated 'Neon,' and a dissonant soundscape interspersed with Morse code beeps spelling out N-E-O-N. The succession of these specific parts consequently formed a fragmentary whole of distortive audiovisual impressions, which were meant to assault and provoke the senses. And as the last still shot underlined, viewers were encouraged to make a Neon code themselves and send it to a P.O. box in Hilversum.

The Neon codes' small-scale formal characteristics functioned as a general blueprint for the unusual TV programme as a whole. On a macro level, the programme can be regarded as an audiovisual collage that was constituted from several heterogeneous elements. In its first episode, Neon featured a volatile string of images and sounds, which was further created with pirated fragments of soft-core pornography and Hollywood movies.

It can be argued then, that Neon was a multimedia production with a strong punk ethos. More generally, the programme was inspired by what was later conceptualised as the 'punk project.' ${ }^{24}$ Coined by music sociologist Stacy Thompson, the punk project was not strictly confined to the development of a music genre as such; it brought forth a scene that was invested in a wide array of DIY cultural productions such as collages, magazines, films, fashion, etc. ${ }^{25}$

The 'anonymous' team behind Neon employed an aesthetically obtrusive and multimodal form of audiovisual communication. This specific form of communication emerged from an unconventional mode of DIY media production that was unseen before in Dutch broadcast TV practices. And as the following sections will explore further, Neon pursued an explicit participatory agenda.

\subsection{Neon as Participatory Video Culture}

The Dutch press picked up on Neon's unconventional nature and recognised it as a notable, yet slightly impalpable example of a contemporary television programme for an adolescent audience. ${ }^{26}$ Asked for a characterization of the programme, VPRO's press officer Ad Kooyman made sure that the participatory ambitions of the TV programme came across. He underlined that Neon could serve as a platform for those youngsters who are not members of the Dutch media establishment, with Hilversum as its broadcast capital. ${ }^{27}$

As a consequence of their lack of access to mass media, this group remained underrepresented and did not have the means nor the infrastructure to create their own TV content. As the press representative understood it, this was an important aspect of Neon's existence because the programme aimed at providing the proper infrastructure for self-made media productions. He believed that Neon would be the first step towards a progressive 'video culture' in the Netherlands. ${ }^{28}$

This notion of 'video culture' is quite remarkable, since it connected the punk video project with the lively debate surrounding video as a democratic medium. According to media theorist James Moran, much of the debate on amateur video technologies in the 1970s revolved around the normative notion that users should appropriate them in order to be

23 Dick Hebdige, Subcultures: The Meaning of Style, Routledge, 1979, p. 105-106.

24 Stacy Thompson, Punk Productions: Unfinished Business, SUNY Press, 2004, p. 3.

25 Thompson discerns five forms of punk 'textuality,' namely music, style, the printed word, cinema and events. See: Idem, p. 105.

26 Yvonne Gnirrep, 'Niets tussen Jan de Bom en Frank Ross: Jeugd, soms drama, soms gevarieerd,' De Waarheid, December 22 1979.

27 Idem.

28 Idem. 
Tom Slootweg and Susan Aasman, Democratic Television in the Netherlands

aesthetically and politically radical. ${ }^{29}$ Especially the more activist American video avant-garde, who were convinced that video offered possibilities that could be used by anyone willing to challenge the dominance of conservative media institutions such as television. ${ }^{30}$

A seminal example of thinking about the radical potential of consumer video technologies in the United States is Michael Shampberg's Guerilla Television (1971). In this publication Shamberg maintained that portable video would make possible "decentralized production while alternate distribution technologies (...) mean that small-scale, non-mass market information flow can be supported directly by the end user." ${ }^{31}$ Taking a stance towards the perceived hegemonic powers of what he termed institutionalised 'Media-America,' Shamberg believed that video would be a key 'countertechnology' in order to achieve a form of 'do-it-yourself TV.'32

Shamberg was intimately associated to the avant-garde magazine Radical Software (1970-1974) with eminent collaborators such as Nam June Paik, Frank Gillette and New Age guru Dean Evenson. ${ }^{33}$ This magazine once stated that portable video is "the natural medium" with which to achieve a revolutionary "decentralized communications system which [sic] allows free expression to all." ${ }^{34}$

Neon can be seen as a Dutch exponent of this revolutionary understanding of video's participatory potential. Its creators reformulated their progressive ideas around its potential in terms of the punk project and the ethos that underpinned it. Embracing the punk attitude of participation and inclusion, the earlier mentioned press representative urged everyone to regard Neon as an 'audio-visual P.O. box.'

An anonymous member of Neon's production team formulated this even more provocatively and claimed that the programme will help people resist "the undemocratic use of the airwaves." 35 Taking inspiration from the development of independent cable television networks in the United States, Neon hoped that the Netherlands would soon provide a comparable infrastructure of alternative video production on television. ${ }^{36}$

The VPRO press officer endorsed these ideas about video as an important counter-technology as much as he could. Pointing at the innovations in consumer video technologies in terms of miniaturisation, cost-reduction, and ease-of-use, he speculated that video would soon be available to everyone. A critical remark made by a journalist, who doubted the broadcast quality of consumer video, was brushed aside. Paraphrasing the 'anonymous' producers, he replied: "we couldn't care less about the quality standards dictated by Hilversum. We have our own standards." ${ }^{37}$ Furthermore,

29 James M. Moran, There is no Place Like Home Video, University of Minnesota Press, 2002.

30 Moran extensively analysed the way in which video became intertwined with the revolutionary "goals of progressive media discourse" for alternative forms of participatory practice. See: Moran, p. 79. Especially Hans Magnus Enzensberger's writings on a new 'Marxist media theory' were an influential source of inspiration for this discourse. See for example: Hans Magnus Enzensberger, 'Constituents of a Theory of the Media,' in New Left Review, 64, 1970, p. 13-36.

31 Michael Shamberg, Guerilla Television, Holt, Rinehart and Winston, 1971, p. 32-33.

32 Idem, p. 8.

33 Radical Software was published by video collective Raindance Corporation (1969-1997) based in New York. This collective was certainly not the only one with distinct ideas about the radical potential of video in terms of media participation and democratisation. Outside the United States, there were other video groups that shared a similar outlook on this potential of video. In the Netherlands, for instance, Meatball (1972-1994), see also note 36 .

34 Dudley Evenson, 'Portable Video: The Natural Medium,' in Radical Software 1, 5, 1972, p. 55-57, cf. p. 57.

35 “[...] een ondemocratisch gebruik van de ether." Translation TS. Quoted in: 'Neon: illegale berichten van de onderkant van onze samenleving,' Leeuwarder Courant, November 291979.

36 This argument is very similar to what Burch has described as the development of 'alternative folk television' in the United States. See: Elizabeth Burch, 'Getting Closer to Folk TV Production: Nontraditional Uses of Video in the U.S. and Other Cultures,' in Journal of Film and Video, 49, 4, 1997, p. 18-29, cf. p. 18. A history of folk TV or more specifically video culture in the Netherlands has yet to be written. A modest account of several 'social,' rather than strictly artistic video collectives in the Netherlands, such as Meatball in The Hague and Open Studio in Amsterdam, can be found in: Rob Perrée, 'Van Agora tot Montevideo: Van video-instituten, de dingen die voorbij gaan,' in Jeroen Boomgaard and Bart Rutte, eds, De magnetische tijd: Videokunst in Nederland 1970-1985, NAi Uitgevers, 2003, p. 51-76. A more elaborate historical account of the Hague video collective Meatball will be made available in the forthcoming dissertation by TS. For a history of cable television in the Netherlands, see: Paul Bordewijk, Goud in de grond: De geschiedenis van draadomroep en kabeltelevisie toegespitst op Stadskabel Leiden, Primavera Pers, 2004.

37 "[...] we hebben schijt aan die kwaliteitsnormen van Hilversum, we hebben onze eigen normen." Translation TS. Quoted in: Gnirrep, 'Niets tussen Jan de Bom en Frank Ross.' 
Tom Slootweg and Susan Aasman, Democratic Television in the Netherlands

VPRO's TV director Roelof Kiers emphasised elsewhere that he has no intention to interfere with the content of the programme, because he considered Neon to be an "experiment of democratisation on television." 38

\subsection{Shapingthe Neon Aesthetic}

The initial impression of a programme driven by an anonymous fringe group with a complete disregard for TV broadcast conventions, however, is not supported entirely by sources from the VPRO Archives. Additionally, interviews with members of the production team, in which they disclosed their names and background after Neon's original broadcast, debunked this impression further. ${ }^{39}$ Ireen van Ditshuyzen, initially known as Ireen van D. in the press, was employed at the VPRO and functioned as an intermediary between the Neon team and VPRO's TV core group (TV-Kerngroep); a subdivision in the broadcaster's central editorial structure that was responsible for its TV productions. ${ }^{40}$

Although the VPRO commissioned the programme with enthusiasm, one of the earlier concerns revolved around the full title: Neon: An Illegal Programme for Resisting Youths at Secret Addresses ('Neon: illegaal TV-programma voor ondergedoken jongeren in het verzet'). The VPRO suggested that the programme could benefit from a less 'pretentious' title that was more to the point, such as "Neon: A Programme for Youths." ${ }^{\text {"1 }}$ Besides the skirmish about the title, the broadcaster was not convinced of Neon's first episode; it was perceived as a chaotic and incomprehensible string of low quality images and sounds. The Neon team did not welcome the suggestion. In an extensive interview published in the summer of 1980, several Neon members hinted at the occasional friction that existed between the production team based in Rotterdam and the VPRO in Hilversum. ${ }^{42}$



Fig. 3 Examples of non-video graphic contributions: "shove it up yours," and "policemen are also human beings." Source: Kooyman and Proper, eds., VPRO-Jaarboek 2, pp. 154-155.

38 'Neon: illegale berichten van de onderkant van onze samenleving,' Leeuwarder Courant, November 291979.

39 Theo van Stegeren, 'De Neon-methode,' in Skrien, July \& August 1980, p. 30-35.

40 VPRO Archives, Hilversum (hereafter VA), TVK 143.11, minutes, 'TV-Kerngroep,' October 29 1979, p. 1.

41 “[...] een programma voor jongeren.” Translation Author TS. See: VA, TVK 143.11, minutes, 'TV-Kerngroep,' October 291979 , p. 1.

42 Van Stegeren, 'De Neon-methode,' p. 32. 
Nonetheless, VPRO's programme director publicly repeated his endorsement of Neon's ambition to offer a platform for marginalised members of society. ${ }^{43}$ In the first two months of its existence, the majority of DIY contributions consisted mostly of cartoons and collages (Figure 3) made by anonymous youngsters, reacting to the request to send in their own material. As the amount of video contributions proved to be negligible, the producers decided to purchase several inexpensive Single-8 Fujica cameras. They were handed out or dispatched by mail to those viewers who reached out to the programme with the wish to make their own footage. This was Neon's economic solution for the development of a participatory video culture in the Netherlands without the exclusive use of video technologies.

\subsection{Voicing Concerns of Antisocial Behaviour}

As Neon was developed further, many more items were made by or covered ex-convicts, hooligans, moonlighters, conscientious objectors, and, even more controversial at the time, squatters. This troubled the intermediary between the VPRO and the production team. As a result she started to question the disproportionate focus on civil disobedience and the anti-social behaviour of the more aggressive subcultures. ${ }^{44}$

Several social commentators were also extremely concerned with the bleak and aggressive attitude demonstrated by punks and other youth subcultures. As a commentator described it in 1977:

Ugliness, dirt, obscenity and the vulgar are part of what they see as the pivot of beauty. They preach hate and disgust. They aggressively rebel against a society in which they have become outcasts [...]. Many dull themselves with the joyless consumption of alcohol, drugs and sex, or with violence and crime. ${ }^{45}$

A regional television critic voiced similar moral concerns. He saw Neon's presence on television as a catalyst for the aggressive outgrowing of those youth subcultures at the turn of the decade. In his view, the programme glorified an extremely nihilistic worldview and "encouraged youngsters to willingly commit acts of antisocial behaviour."46

Neon did not only evoke moral outcries. A fifteen-year-old girl praised the programme for its honesty and relevance: "I'm of the opinion that Neon is the best youth programme ever made. Many people at my school also share this view. Everybody was talking about it on the Mondays after the broadcast." ${ }^{47}$ For her, a controversial item in Neon I about a pupil who vandalised school toilets out of frustration with hierarchical society was a topic she could relate to.

\subsection{Mounting Controversies and Censoring Neon}

Notwithstanding the lively debate around the programme, VPRO's TV group did not immediately intervene in or halt its production. However, the support diminished when the VPRO saw a rough cut of 'Neon 7' in which numerous implicit and explicit references were made to the militant left-wing organisation Rote Armee Fraktion (RAF). The VPRO deemed the references to the RAF in Neon as a dangerous glorification of terrorist attacks (e.g. bombings, kidnappings and hijackings). ${ }^{48}$

43 Ale van Dijk, 'Perfectie hoeft niet, we willen wat zéggen,' Het Vrije Volk, December 1, 1979.

44 Van Stegeren, p. 34.

45 “Lelijk, vuil, obsceen en ordinair is hun hoogste schoonheid. Zij prediken haat en walging. Zij schoppen tegen een maatschappij aan, waarin zij verschoppelingen zijn. [...] Velen van hen vluchten in vreugdeloze alcohol, drugs en seks, of in geweld en misdaad.” Translation TS. See: 'Verloren generatie,' Leeuwarder Courant, November 261977.

46 Cor van der Poel, 'Zo mag ik 't zien,' Leeuwarder Courant, February 181980.

47 "Ik vond Neon het beste programma wat er ooit voor de jeugd is gemaakt. En zo denken veel mensen bij mij op school erover." Translation TS. The writer of the letter is Jella van Santen. Cited in: Kooyman and Proper, p. 73.

48 VA, TVK 143.11, minutes, 'TV-Kerngroep,' March 17 1980, p. 1. 
Tom Slootweg and Susan Aasman, Democratic Television in the Netherlands

Contrary to what was stated in the press, there was a contractual agreement that stipulated the right of the broadcaster to intervene if necessary. When the episode was broadcast on March 16, 1980, a part of 'Neon 7's soundtrack, which compared the persecution of RAF with the Nazi's execution of German resistance fighters, was censured by means of a high-pitched beep.

The broadcast of Neon 8 on April 13, 1980, turned out to be "the final straw." ${ }^{49}$ Besides the sensitive relationship with the VPRO, internal struggles within the Neon team itself started to become more problematic. Almost twenty-two years later, two members recounted that the controversy surrounding 'Neon 8', but more importantly the censorship of to the previous episode, was a blessing in disguise: "[it] actually played out very well for us. It gave us the chance to be outraged and to cry out 'how dare you!' But after eight episodes we were happy to round things up." 50

The news that Neon would stop after eight episodes delighted Frits Abrahams, one of Neon's most influential critics:

Starting full of promise, the programme turned out to be quite a disappointment. The pretentious artistic ambitions behind Neon irritate me immensely. Its creators only seem to indulge in their self-proclaimed role as television innovators: their footage couldn't be more unsteady and incomprehensible, since only than, I suspect, will it truly be artistic. ${ }^{51}$

The specific graphic language of resistance clearly underwhelmed the critic. The jury members of the annual Cinemagia Prize - an award issued by the Netherlands Association of Audiovisual Professionals (NFB) - did not agree with the negative assessment of the programme. The jury lauded Neon because "[it] did not only function as an ironic, critical and eye-opening commentator of the closed nature of the media establishment in the Netherlands - 'NEON' furthermore showed that the traditional disciplines related to the use of film, video and television are in dire need of reinterpretation." 52

Skip to: Introduction, Case Neon or Bringing the cases together

\section{Case Mr. Ed}

\section{1 Super-8 on Television}

On March 30, 1980 the VPRO presented a new documentary Adventures in the Countryside ('Avonturen op het land') by veteran filmmaker Ed van der Elsken. ${ }^{53}$ This film was shot on Super-8 film and it showed his life around his house, in the countryside where he lived. Ed van der Elsken was at the time famous for his photos of street life, so the filmic portrait of birds, water fleas and cows instead of people, was surprising in view of his earlier work.

49 This episode focused on the squatting community in the Netherlands. Only several weeks after broadcast, the squatting community and others violently disrupted the investiture ceremony of Queen Beatrix in Amsterdam on April, 30, 1980. The violent clash between the riot police and protesters on that day caused a considerable national controversy, as well as among the Neon team members themselves. See: Elenor Jonker, No Future Nu. Punk in Nederland 1977-2012, Lebowski, 2012, p. 181

50 Frank Kools, 'De Undergroundtelevisie van Neon,' 2012.

51 "Het programma startte ook vol beloften, maar het is me dit seizoen gaandeweg steeds meer tegengevallen. Wat mij vooral irriteert, is de artistieke pretentie die van Neon uitgaat. De makers willen te veel de tv-vernieuwers uithangen: de opnamen kunnen niet schokkerig en onbegrijpelijk genoeg uitvallen, want dan begint het echt op kunst te lijken." Translation TS. Frits Abrahams wrote for the progressive quality newspaper De Volkskrant. Cited in: Aad Kooyman and Rogier Proper, eds, VPRO-Jaarboek 2: De beste teksten van het seizoen 1979/80, Erven Thomas Rap, 1980, p. $154-155$.

52 " [...] functioneert het programma niet alleen als een ironische, kritische en blik-verruimende commentator op het gesloten karakter van het Nederlandse media-establishment-'NEON' heeft tevens laten zien dat de traditionele disciplines in het hanteren van film, video en televisie in ruime mate toe zijn aan herinterpretatie." Translation TS. See: VA, 284, report of the jury by Kees Hin, Hans Keller and Jos Vrijburg, 'Cinemagiaprijs 1979,' April 26 1980, p. 2.

53 For an analysis of this documentary, see: Susan Aasman, 'Avonturen op het land: Een persoonlijke natuurfilm van Ed van der Elsken,' in Tijdschrift voor Mediageschiedenis 12, 2, 2009, p. 275-287. 


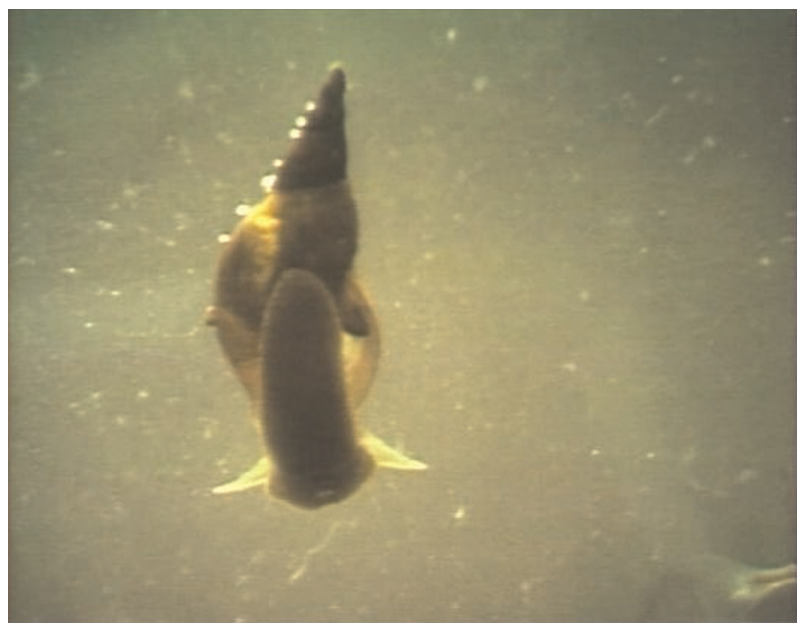

Fig. 5 Screen capture from Adventures in the Countryside.

Copyright Anneke Hilhorst, Netherlands Institute of Sound and Vision.

One year later, Van der Elsken produced another Super-8 documentary for television: Mr Ed and the Talking Film ('Mr Ed en de sprekende film'). In this film, he presented a series of home movie-like travel reports about himself, his wife and one-year-old son on the road to France.

In both documentaries the filmmaker and photographer improvised heavily, a method he believed was only possible because of his use of Super-8, at the time a common and everyday consumer media technology. Van der Elsken was convinced that Super-8 allowed for a much higher degree of spontaneity. So when his neighbour informed him that a cow was about to give birth, Van der Elsken was able to react immediately, without any cumbersome technical preparations. ${ }^{54}$

Sometimes this method resulted in shots that were out of focus, but the filmmaker accepted this as part of his ethos. To Van der Elsken the real challenge was to bridge the gap between life and art. Art was emotion, and with that conviction he disagreed with his friend and fellow filmmaker Johan van der Keuken who treated life as form. ${ }^{55}$ Another feature of Van der Elskens documentaries was the lack of a strong narrative cohesion. For example, Adventures in the Countryside ends because, as his voice-over explained: "It's time this documentary comes to an end."

Inspired by his own experiences with amateur media technologies, he hoped to encourage his viewers to participate and make films themselves. In addition, he imagined that the amateur film camera could become a tool for resistance, particularly in politically repressive situations. The following section will explore whether Van der Elsken really subscribed to a political agenda. How did Van der Elsken attribute significance to alternative media technologies as counter technologies?

\subsection{Super-8 and the Avant-Garde as Alternative Media}

Ed van der Elsken (1925-1990) had started his career as a photographer and received critical acclaim for his work. ${ }^{56}$ Despite this success, he also embraced the film camera in the early 1960s, and, since then, occasionally worked as a cinematographer, for instance as a freelance cameraman or as an independent director.

54 Ale van Dijk, 'Super-8 wordt een politiek wapen, interview met Ed van der Elsken,' Het Vrije Volk, May 51981.

55 Johan van der Keuken, 'Ed van der Elsken tussen foto en film', in Flip Bool, ed, Leve ik!, Paradox, 1997, p.55-61, cf. p. 56.

56 Before he became a filmmaker he was a successful photographer and remained active in that profession. Some of his best known books are: Love on the Left Bank, Andre Deutsch, 1966; Sweet Life, De Bezige Bij, 1966; Eye Love You, Van Holkema \& Warendorf, 1977. See for more on Ed van der Elsken: Evelien de Regt, Once upon a time: een biografie, Fragment, 1991; Flip Bool, ed, Leve ik!, Paradox, 1997. 
Respected by many film and television makers because of his technical skills, Van der Elsken's idiosyncratic photographic style was widely acknowledged. ${ }^{57}$ This style can be described as highly expressive and emotional, which was furthermore emphasized by a very insistent personal presence. His first documentary Welcome to Life, Dear One ('Welkom in het leven, lieve kleine,' 1963) exemplified a translation of his photographic style to film.

Throughout his career, Van der Elsken's work remained close to his personal life, as he shared his domestic life on national television without any hesitation. When the filmmaker received a national prize for his documentary The Infatuated Camera ('De verliefde camera,' 1971), a film critic attacked this personal style as an "abusive self-portrait.".58 But Ed van der Elsken did not mind. Being a complete 'authentic autarkist,' as independent film historian Hans Schoots characterised him, he strived for absolutely pure and direct form of communication, to get as close to life as possible. ${ }^{59}$

Ed van der Elsken held an ambivalent relationship to the world of television. He preferred it as a more accessible medium: in an interview, he would describe cinema as a phenomenon that was in poor health, whereas television as a medium of transmission was on the rise. ${ }^{60}$ At the same time he disliked this medium, which Van der Elsken found to be governed by conformism and strict deadlines. Although VPRO programme makers hired him quite regularly (as a cameraman), he gradually placed himself more and more on the fringes of Hilversum. He retreated from the world of professional television making as he started (preferring) to work as an independent filmmaker in close collaboration with his wife Anneke Hilhorst. ${ }^{61}$ In search for economic and artistic independence, he devoted himself to Super-8 film. With this affordable and easy to use technology he made several documentaries for television.

\subsection{AmateurFilm CuIture as Avant-Garde}

With his choice for amateur film technology, Van der Elsken stepped into a long avant-garde tradition. It is possible to trace back this tradition to the 1920s; but it is the emergence of underground cinema in the United States from the 1960s onwards, which is especially important to contextualise Ed van der Elsken as a filmmaker.

Avant-gardist like Jonas Mekas and Stan Brakhage were early influential contributors to this tradition, as they sought to bring art and everyday life closer together. ${ }^{62}$ Another famous example would be Ed Pincus, who together with Richard Leacock, worked at MIT where they influenced many documentary filmmakers in developing a radically personal approach using $8 \mathrm{~mm}$ equipment. ${ }^{63}$ These artists embraced everyday consumer technologies in order to explore new ways of filmmaking and eventually developed a more autobiographical form of cinema. ${ }^{64}$

Van der Elsken fitted perfectly in this avant-garde mode, since he considered himself to be an individual non-conformist. His oeuvre shows a similar fascination with an intimate and personal cinema: by exploiting his presence in and through his films, denying the conventions of public and private, and by celebrating the value of emotions on screen.

56 Before he became a filmmaker he was a successful photographer and remained active in that profession. Some of his best known books are: Love on the Left Bank, Andre Deutsch, 1966; Sweet Life, De Bezige Bij, 1966; Eye Love You, Van Holkema \& Warendorf, 1977. See for more on Ed van der Elsken: Evelien de Regt, Once upon a time: een biografie, Fragment, 1991; Flip Bool, ed, Leve ik!, Paradox, 1997.

56 Before he became a filmmaker he was a successful photographer and remained active in that profession. Some of his best known books are: Love on the Left Bank, Andre Deutsch, 1966; Sweet Life, De Bezige Bij, 1966; Eye Love You, Van Holkema \& Warendorf, 1977. See for more on Ed van der Elsken: Evelien de Regt, Once upon a time: een biografie, Fragment, 1991; Flip Bool, ed, Leve ik!, Paradox, 1997.

57 Bert Hogenkamp, Direct Cinema, maar soepel en met mate, Stichting Nederlands Filmfestival, 2006.

58 “Ongehoord zelfbevredigingsportret." Translation SA. See: Interview Peter van Bueren, Skoop, 1971, 8, p. 25-26.

59 Hans Schoots, 'Ein Authentischer Autarkist,' Ed van der Elsken: Fotografie + Film, 1949-1990, Hatje Cantz, 2000, p. 92-95.

60 Hogenkamp, Direct Cinema, p. 36.

61 Interview with Anneke Hilhorst in Jan Bosdriesz, Het Uur van de Wolf, NPS 25-11-1996.

62 See for example: David E. James, ed, To Free the Cinema: Jonas Mekas and the New York Underground, Princeton University Press, 1992; David E. James, ed, Stan Brakhage: Filmmaker, Temple University Press, 2005; P. Adams Sitney, The Cinema of Poetry, Oxford University Press, 2015. 63 Jim Lane, 'The Career and Influence of Ed Pincus: Shifts in Documentary Epistomology,' in Journal of Film and Video, $49,4,1997$, p. 3-17.

64 For a further reflection, see: Susan Aasman, 'Broadcast Yourself: New Media Technologies and the Democratisation of Truth and Trust,' in Chris Peters and Marcel Broersma, eds, Retelling Journalism: Conveying Stories in a Digital Age, Peeters, 2014, p. 47-64. 
Also his political views resembled those of an outsider, as he kept his distance from institutions. Amateur technology offered affordances that enhanced his ability to work independently. As Jan-Christopher Horak explained, this preference for spontaneity, authenticity and freedom of movement was valued more than technical perfection. ${ }^{65}$

Yet, there is one main point where Ed van der Elsken differed from his fellow filmmakers: he did not strive to be an experimental underground filmmaker. He did make some experimental films, especially in the 1960s, but unlike his friend Johan van der Keuken, he did not participate much in the international scene of avant-garde artists. ${ }^{66}$

As we have already explained, Van der Elsken initially preferred public television, even though he would keep his distance from the medium at the same time. What he liked about television was the fact that it offered him a platform to distribute his films and make them accessible to a wide audience. Furthermore, he wanted to teach his audience that what he could bring to the television screen-filming a cow, taking a camera along while on vacation, or even entering a country under a repressive regime-was also possible for them.

By giving his TV audience concrete examples of ways in which to record one's own life, garden and holiday, he hoped to inspire an amateur film culture. As he explained in a newspaper: "What I consider to be the most important aspect of this technology is that everyone can do it." ${ }^{\text {67 }}$ Of course, Van der Elsken spoke here as a professional filmmaker, but he anticipated a period when these do-it-yourself films might even be broadcast on television.

The costs did not need to be a barrier to either the filmmaker or television chiefs. As he claimed in Mr Ed:

Super-8 is a technology that will stay, because it has the advantage of being affordable. Broadcasters like the VPRO can easily pay for it [...] This will be nothing like Hollywood's Cecil B. DeMille who used a thousand extras and a technical crew, which costs 10.000 Dutch guilders a day. What we do will only costs us a daily 100 guilders. $^{68}$

\subsection{Super-8 as Political Weapon}

To Van der Elsken, it was not enough to stimulate amateur filmmaking as a hobby. He added a more political agenda, because he believed Super-8 should become a political weapon. He told his audience in Mr Ed that this weapon has to be used "against all those liars in every police state, from left to right. At the border they can obstruct the access of official foreign television reporters, who carry their bulky 16-mm equipment, but they can't stop those thousands of tourists with little 8-mm cameras." ${ }^{69}$

This more activist discourse on amateur media had slowly emerged in the early 1970s. Notions of access through the availability of amateur media technologies can be found elsewhere as well. In 1975, UNESCO published a report entitled Super 8: The Modest Medium. In this report, Jonathan Gunther predicted an 8-mm revolution that would give ordinary people access to a medium in order to participate in the public sphere. Although this UNESCO report emphasised the opportunities in Third World countries, it promoted the more general idea that Super- 8 could become a counter-technology insomuch as it was a communicational tool that people could use to portray a variety of problems.

65 Jan-Christopher Horak, 'De verliefde camera: De films van Ed van der Elsken,' in Flip Bool, ed, Leve ik, Paradox, 1997, p. 31-53.

66 Except for a visit to the Oberhausen Film Festival in 1965 of which he made a short documentary titled: Germany, Oberhausen, XI Westdeutsche Kurzfilmtage.

67 “Wat bij mij voorop staat: iedereen kan dat." Translation SA. Quoted in: Van Dijk, 'Super-8 wordt een politiek wapen.'

68 This quote is transcribed and translated by SA from the raw footage of Mr Ed and the Talking Film.

69 "Super-8 film wordt een politiek wapen, een wapen voor de vrijheid, tegen al die leugenaars in alle politiestaten van links en rechts en die kunnen wel een officieel buitenlands televisie team met zware $16 \mathrm{~mm}$ apparatuur bij de grens tegenhouden, maar niet die duizenden toeristen met hun $8-\mathrm{mm}$ cameraatjes." Translation and transcription SA. 


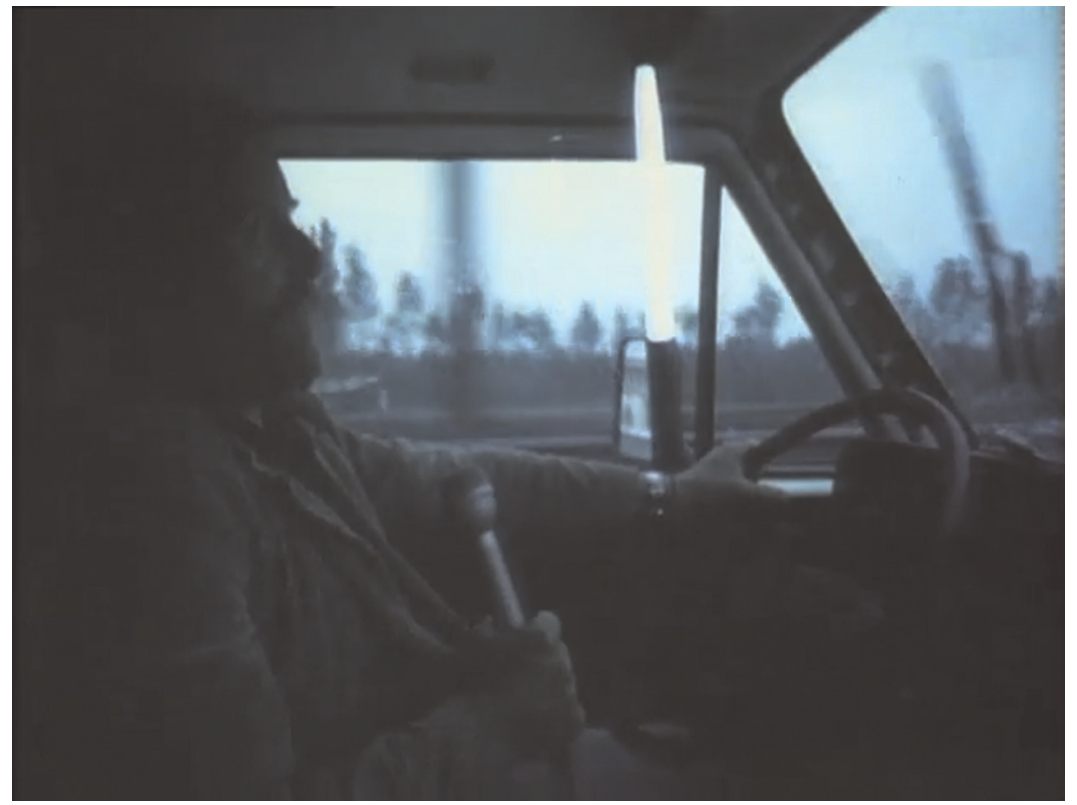

Fig. 6 Mr. Ed and the Talking Film. Go to the online version of this article to see the full video. Copyright Anneke Hilhorst, Netherlands Institute of Sound and Vision.

In short, the report reflected a strong utopian belief that social revolutions can be enforced through (media) technological means. Several others, all pointing to the idea of accessibility and participation, followed the report by Gunther. ${ }^{70}$ At the same time, filmmakers started to explore the technical possibilities of Super-8 as a professional technology. The famous independent filmmaker Lenny Lipton wrote several popular books on the film format, and taught people the tips and tricks of serious 8-mm filmmaking. ${ }^{71}$ In 1975, the American Cinematographer exhaustively explored the format by publishing a special issue on the possibilities and constraints for (semi) professional use. ${ }^{72}$

\subsection{Bringing Sound to the Amateur}

During his career Van der Elsken was rather consistent in his approach to filmmaking. He emphasized his presence in all of his films: sometimes as the man behind the camera, who is clearly audible through his comments, or, in other cases, as the man in front and behind the camera. This style and narrative strategy did not only result in a distinctly personal presence in his films, it also offered a reflection on the process of filmmaking itself and thus gave it a sense of authenticity.

By including his struggles with the camera and microphone, Van der Elsken implicitly argued that craftsmanship-or even better, failures of craftsmanship-should not hinder the filmmaker. He never strived for perfection because authenticity

70 Other papers published by UNESCO understood small-gauge film, but also video, as part of community media. See F. Jouet, 'Community Media and Development: Problems of Adaption,' working paper, UNESCO, 1977; Frances Berrigan, 'Access: Some Western Models of Communicative Media,' working paper, UNESCO, 1977; Frances Berrigan, 'Community Communications: The Role of Community Media in Development,' working paper, UNESCO, 1979.

71 For instance: Lenny Lipton, The Super-8 Book, Simon and Schuster, 1975.

72 See the special issue on 'The state of the Art of Professional Super 8,' in American Cinematographer, 56, 11, 1975. 
Tom Slootweg and Susan Aasman, Democratic Television in the Netherlands
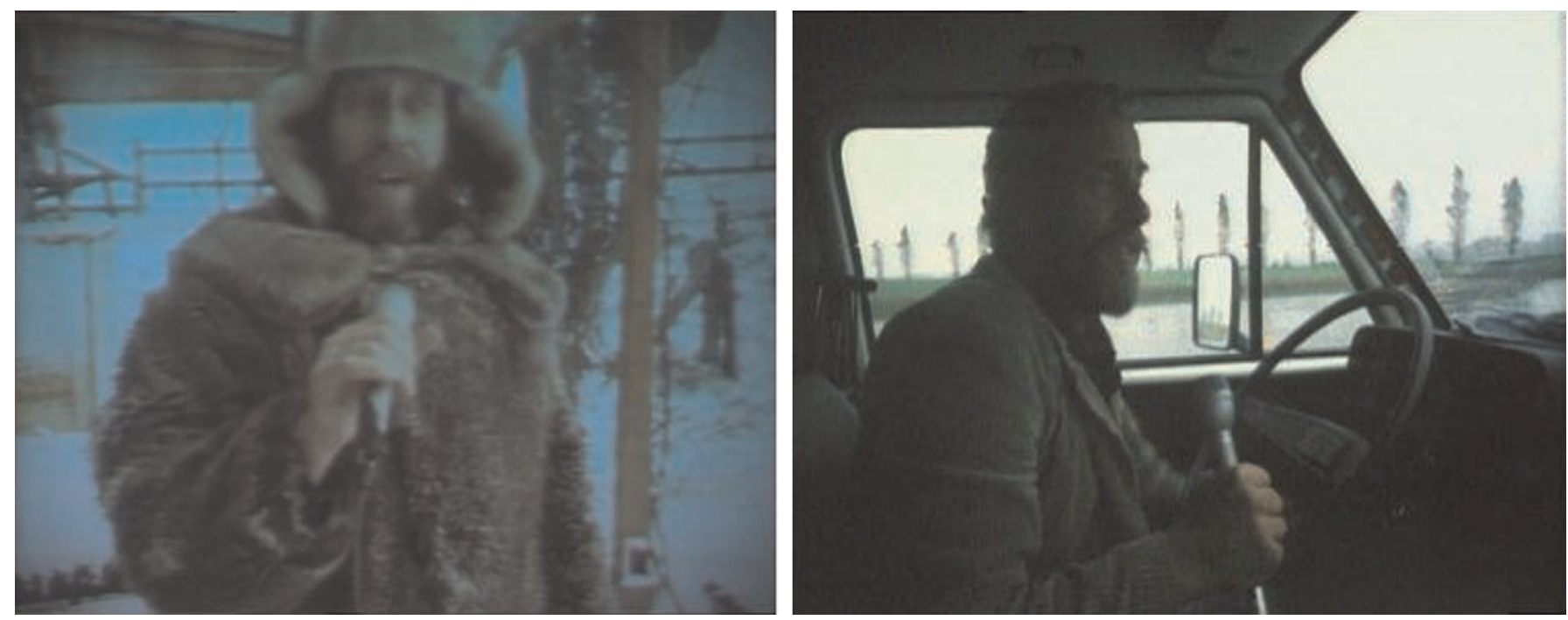

Fig. 7 Screen captures from Adventures in the Countryside and Mr. Ed and the Talking Film. Copyright Anneke Hilhorst, Netherlands Institute of Sound and Vision.

was far more important to him. Rather explicitly, he kept mistakes in the film, so that he could comment on them. This also happened in $\mathrm{Mr}$ Ed:

Oh, yes, I didn't record this scene of our stay in Calais with synchronous sound. And this lack of sound can be an unfortunate thing, I guess. But then again, this is not the end of the world: it is very easy to add sound later, thanks to a variety of modern Super-8 devices. ${ }^{73}$

In an interview about the production of $M r E d$, Van der Elsken boasted that it was most likely the "first big film in the whole world" that tried to edit Super-8 with direct sound. As Van der Elsken saw it, he and his wife Anneke Hilhorst had broken 'the taboo' of making a montage with Super-8 sound film. Now it was time to show that attempt to "the people."

Skip to: Introduction, $\underline{\text { Case Neon }}$ or Bringing the cases together

\section{Bringingthe Cases Together: Happiness versus Nihilism?}

Just before Neon disappeared from the television screen, a former programme director of the VPRO strongly denounced Neon 7 in the station's TV guide. In that same guide, on the opposite page of this rant, filmmaker Ed van der Elsken introduced his documentary Adventures in the Countryside. ${ }^{74}$ His documentary was scheduled in the same time slot where Neon had been programmed. Instead of squatters and punks, Dutch TV spectators were now confronted with birds, cows, frogs, water fleas and everything else that surrounded Ed van der Elsken's house in the countryside. Instead of The Cure, the soundtrack of Adventures in the Countryside featured Beethoven.

Reading the case of Neon it can be concluded that this programme was, more than anything else, a controversial project that fuelled concerns about both the content and the nihilistic attitude of its creators and youthful participants.

73 "Oh ja, deze scène had ik niet met direct geluid opgenomen toen daar in Calais. En dat mis je toch wel hoor. En daar is een gelukje. Je kan het heel gemakkelijk nasynchroniseren met die moderne super 8 apparatuur." Translation and transcription Susan Aasman.

74 Jan Blokker, '81,' De VPRO Gids 13, 1980 13, p. 2.; Harry Hosman, 'Interview met Ed van der Elsken: Ik ben een enorme blitskikker,' idem, p. 3-6. 
Tom Slootweg and Susan Aasman, Democratic Television in the Netherlands

Neon's outlook on life seems far removed from the one expressed in Van der Elsken's films: the happy world of family leisure that was portrayed in $M r$. Ed, contrasted starkly with the destructive and nihilistic characteristics of Neon.

Despite the fact that these two cases can be seen as two very different television productions, we would rather see them in conjunction. We think they can be understood as interrelated cases that share a general discursive motif in media history. Whatever the differences in attitude and aesthetics, both cases, and the surrounding discourses, articulated a deep longing for providing access to or enabling participation of the non-professional or amateur. The idea of television as a democratic project was strongly attached to a hope that amateur media could serve as counter technologies. As such they could oppose the dominant practices within broadcast television.

Additionally, we wanted to understand how our cases played with ideas so as to use them as counter-technologies in order to participate either in or through media. Within this framework they can be seen as two different things, yet highly interrelated articulations of media democratisation and participation.

What turned out to be interesting about the Neon case is that it served as a platform within the institutionalised television landscape. Neon offered a glimpse of what participation in media could be; the programme functioned as an audiovisual P.O. box open to everyone, and as such enabled the right to communicate.

If we evaluate participation through media, by which we refer to forms of self-representation through the use of media technologies, Neon was able to develop with its audience a graphic language of resistance. However, because of its controversial content, Neon invited an ambivalent acceptance by the cultural elites and the audience at the time.

Compared to Neon, Van der Elsken's counter-technological project was more about participation through media. His main contribution was to demonstrate how everyone could learn from his expressive form of audiovisual selfrepresentation on public television. Although his highly personal form of non-conformism can be paralleled to the attitude of underground filmmakers, Van der Elsken wanted to have a wider reach. His goal was to convince the television audience - and perhaps Hilversum as well - of the symbolic value and potential of Super-8 sound film as a democratic and accessible counter-technology.

\section{Democratic Television as a Failed Media Revolution}

In this article we have highlighted the ways in which our cases were imbued with a firm belief in amateur media technologies and their presupposed power to counter the institutionalised Dutch TV broadcast system. Whereas Neon aimed at challenging mainstream TV with a provocative punk-inspired participatory 'video culture,' photographer and filmmaker Ed van der Elsken's documentary series reflected by means of demonstration on the participatory potential of Super-8 sound film as an individual tool for audiovisual expression on public television.

However telling these examples of counter-technologies are, they did not bring about a democratic media revolution; neither the VPRO nor the Dutch public broadcasting system were able (or willing) to provide the infrastructure for such far-reaching forms of media participation at a national level. In retrospect, these two programmes did provide us, nevertheless, with a counter-history wherein we could identify them as remarkable forebears of what was yet to come. From a media archaeological perspective, these curious cases offer a glimpse of specific past recursive motifs of democratic television and media participation. 
Tom Slootweg and Susan Aasman, Democratic Television in the Netherlands

\section{B i o graph y}

Tom Slootweg is a PhD candidate at the University of Groningen. His research focuses on the (often utopian) hopes and expectations surrounding the introduction of video technologies in the Netherlands, with a specific interest in video's appropriation by amateur users as an audiovisual technology of memory. Tom is also a board member of the Dutch Foundation for Amateur Film. His research is part of the NWO-funded project 'Changing Platforms of Ritualized Memory Practices: The Cultural Dynamics of Home Movies.'

Susan Aasman is a senior lecturer and researcher at the History Department at the University of Groningen. She wrote her dissertation on the cultural history of home movies and is currently also working on the NWO-funded project 'Changing Platforms of Ritualized Memory Practices.' She is editor-in-chief of the Dutch Journal for Media History. Over the years, Aasman has written about home movies, cultural memory, mediatisation of politics, autobiographical documentary and first person cinema. 